\title{
Global Configurations of Violence and the (Im)possibility of their Mitigation: An interview with Harry Gould \& Brent Steele
}

Transcribed by: Francine Rossone de Paula, Virginia Tech frossone@vt.edu

Interview conducted by: Francine Rossone de Paula (frossone@vt.edu), Jennifer Lawrence (jennlaw@vt.edu), Kent Morris (ekmorris@vt.edu) - Virginia Tech Additional Questions and copyedit by: Anthony Szczurek, Virginia Tech (anthos9@vt.edu)

Keywords: International Relations - State responsibility - Accountability Violence - National (In)Security

These questions were put together in coordination with some ASPECT students in response to some of the articles that Brent Steele and Harry Gould have shared for the purpose of the seminar "Global Configurations of Violence and the (Im)possibility of their Mitigation", that took place on October 18, 2013. Steele and Gould were interviewed in the afternoon after this seminar. We wanted to take the conversation we had earlier that day and the conversation we had the night before in the ASPECT symposium on Geopolitics titled "Thinking and Writing Critically in International Relations" and to expand it for the purpose of the SPECTRA journal. The interview explores issues and concepts situated particularly in the field of International Relations, while it also speaks to a larger audience interested in the discussions on state responsibility, violence, alternative forms of accountability and the different facets of American national security in the twenty-first century.

Kent Morris: Harry Gould, Brent Steele, thank you for being here for this ASPECT interview for SPECTRA.

Jennifer Lawrence: How might traditional IR (International Relations) theory, which embodies the state with ideas of responsibility and intent, inform 
Transitions, Revolutions, and Reinventions: Discourses on Human Capabilities and World Configurations

contemporary public policy which is burdened by special interests? Do you think it speaks to a larger anxiety of where to locate responsibility and intent in a dislocated global economy where corporations play a role as political agents, in addition to states? How is agency changing? In what ways is this anxiety expressed and this displacement resisted by states?

Harry Gould: One thing to immediately bear in mind is that this role of special interest is in no way uniquely contemporary. It is something that traditional IR theory just simply bracketed. It was there. There was just a conscious decision made on the grounds of method to set it aside. This way you would get the early split in the field between IR theory and foreign policy theory. There was always that recognition that the State is not in fact a unitary monolithically rational actor. But a deliberate decision was made to treat it for certain purposes as if it were one. And then people who were not interested in doing that, but rather in opening the black box (a phrase that Ferguson and Mansbach use in The Elusive Quest), were understood to be doing something slightly different. They were not doing IR theory. They were doing foreign policy analysis or foreign policy theory. So, traditional IR theory has at least been aware that there are competing interests from within the state. Morgenthau acknowledges that pretty plainly.

When you look at the ideas of state responsibility and state intention, of course that's part of a very long trajectory of thinking in the West. And even there, Morgenthau arbitrarily uses Hobbes for that. He even shows that these varying voices are still there. They are just sublimated and they are subjected to the will of the sovereign. And the will of the sovereign is the will of the state. Of course, in a modern state this is much more complicated than simply wanting a correlation 
between one person's will or one person's intention and that of the apparatus of the modern state.

In terms of what traditional IR theory has to tell us, it is really hard to say, because there is a bit of a disconnect that is still there. For the most part, say like neoclassical realism, the people like Michael Williams who are looking at classical realism in their own ways are still not especially interested in prying open these internal decision mechanisms. The idea of state responsibility, which is something that the realists have sort of agonized over because it is a logical extension of the idea of state personality, is something that they do not necessarily buy into. That opens a lot of interesting doors.

There is this desire, not necessarily related to traditional IR theory, to be able to ascribe responsibility. It is a fairly universal impulse. Am I getting in any trouble by talking about the universals of humanity? There is a fairly general human impulse to want to ascribe responsibility for wrongs that happen, for injuries suffered. Of course that responsibility is not always negatively formulated. It is not responsibility just as blame, as if one has an obligation to do something.

Brent Steele: As responsibility to protect?

Harry Gould: Yes. The problem with that is that it is actually a malformulation, because it really is an obligation to protect. At least in legal terms, and that is really where that comes out of. Responsibility arises from violation of obligations. So, colloquially we talk about responsibility in terms of "one is responsible to do something." But here, more strictly speaking, that does not really work. But the point still stands that it is a widely, if not universally, felt impulse to want to be able to ascribe blame or responsibility, and you guys get at the heart of 
it in the way you formulated the question. It is much harder to do so in a globalized economy, in a globalized world, where actors are not anymore as easily treated as discrete separate entities in their own space, or their own space of mutual interaction. The level of interconnection is too great.

Of course, IR people have been saying that since the sixties. It comes in and out of fashion all the time. The interest in corporations was big in the sixties and the seventies, faded out, came back in, faded out again. If you look back at some of the literature published before any of us were born, there is a theme about the disappearance of the state, not quite a Marxist language, but the withering away of the State, and an assumption that these other transnational actors were going to supersede it. So far they haven't. But what they have become able to do has increased in scope. Back in the fifties and sixties, if you were in South America or in Central America, there were certain American corporations you didn't want to get on the bad side of. You wanted to stay on ITT's good side, United Fruit's good side, Anaconda Copper's good side, or you would no longer be in power. But, even then, they were corporations pushing around individual governments of individual countries. In the case of United Fruit, the brother of one of the people on the board was the director of [the] CIA. But now the scope that corporate behavior can have, or the effects of corporate behavior, or even just things that happen to corporations are much more global. ITT never had the same kind of power globally that megabanks have now to upset the entire world economy. Whether it is a matter of responsibility, because they have done something improper, or responsibility for some sort of malfeasance, or just that if something bad happens to them they drag everybody down. 
Kent Morris: What do you see states doing as a way of combatting this? Or are they embracing it?

Harry Gould: There is definitely push back. And I think the locations of that resistance are largely the same as they were in the sixties and seventies. It is the less developed world, the America-Sur states, whether it is through overt means that were used back then, like nationalization, expropriation, or whether it is just in genuinely "you're not welcome here, your money is not welcome here, your influence is not welcome here." But I don't think that more globally, there is that kind of push back. I think that corporations are too deeply implicated in the economy as in the governments of the wealthier nation-states for them to view it as a reasonable possibility of pushing back against their presence.

Kent Morris: So, rather than a conflict, you would say it is a partnership? Harry Gould: Yes, not always a happy one, of course. We are seeing in the United States and the Republican Party now that big business is starting to have some reservations about the people they put into office three years ago

Kent Morris: The coming of age of corporate political power?

Harry Gould: I think they are just realizing that they may have backed the wrong horses in 2010. You know, there has been for a long time, at least since the Reagan years, an alliance between the GOP and big business. But now that the GOP is so fractured, that partnership is under some strain.

Kent Morris: A side question: Sovereignty is claimed to be waning by many theorists, Wendy Brown included. I would say maybe that it's more like Hardt \& Negri's notion of sovereignty being transformed in a way, or transferred, which kind of goes against the whole notion of sovereignty. The point is: do you see a sort of 
transfer of sovereignty to these non-state corporations? Maybe they have such great influence and impact that they are directing global affairs more so than traditional states have in the past.

Harry Gould: There has definitely been flirtations with it, but I don't think that there is a willingness outright to transfer all functions of governance to corporate actors. There is this discourse in the US that government should be run like a business. But all one needs to do is go back to whatever economist in the liberal tradition, even the Vienna tradition, to remember that the market is not the best solution to all problems. I think that there is not yet any willingness to go that far. I mean, there are sort of these dystopian visions of a world where governments have been supplanted by global corporations.

Jennifer Lawrence: Maybe there is not so much of a transference of sovereignty, but an allowance of sovereignty. There is a book that came out called Private Empire: ExxonMobil and American Power, which argues that Exxon is allowed to operate as a sovereign.

Kent Morris: I wouldn't say transference. I would say the equivalent of acting and having the effect of being sovereign.

Harry Gould: If we shift the language, there are parallel regimes. Sovereign states decide, whether truly voluntarily or under economic coercion, not to exercise certain of their rights and authority vis-à-vis corporations. They just decide not to bind them to the rules or not hold them to some standards. I guess, in certain parts of the world, like the Niger Delta, where corporations are effectively controlling territory. But that's not new. The various East Indian Companies controlled territories, and most of the American colonies were originally corporations. It is not 
a new phenomenon. Obviously, it differs in extent. But I think it is important to bear in mind the example of East Indian Companies. That level of outright control of all facets of sovereignty over a chunk of territory is something we are not yet seeing.

Francine R de Paula: From your perspective, what are the circumstances whereby states grant private mercenary armies the right to wage war against state actors? What are the implications for state sovereignty as a result of the practice of outsourcing what is traditionally understood as the duty of the state to non-state actors? If the state outsources the use of force, what language has been created, and through what practice has it been created, to legitimize the use of force by private security companies?

Harry Gould: There are a couple of things going on here. One immediate response before looking at the historical relationship between privateers and governments is that outsourcing might be loading the dice. Maybe authorizing is a better and less prejudicial term. Connotatively, outsourcing is looked down pretty negatively. Historically, governments have authorized private actors to use force on their behalf, simply when they, for whatever reasons, didn't have the resources to fund the military or, more importantly, fund the construction of the military hardware. Why did the early US republic authorize privateers? It was because it is cheaper to pay people to do it than to train and equip people to do it and build ships for them. I think, generally, it is a resource matter. And today, Private Military Companies (PMCs) are a huge concern, though in the last couple of years, I suppose corresponding to the US withdrawal from Iraq, they have become much less visible, and much less problematic. 
That line of work is actually becoming much less lucrative for these corporations. In recent US usages of PMCs, to the best of my knowledge, they haven't been utilized against other states. They've been utilized against non-state actors, whether it is Al Qaeda or whether it is a different Sunni insurgency in Iraq or a Shia insurgency in Iraq. We've used them to supplement the army or the military against non-state actors, for example by putting PMC personnel on ships in pirate prone waters. Now, obviously, if this were to become a more widespread problem, our contemporary understanding of sovereignty would be challenged in a lot of ways. But if we look at the US use of privateers, it is still in the United States' Constitution. Congress can still authorize us if we can all go in together in a nice boat. We can still be privateers if Congress grants us letters of marque and reprisal. But remember that, for a good chunk of the Renaissance and early modern period, a lot of states didn't have standing armies and they paid mercenaries to do their fighting for them.

I think that a lot of what is at work in this question is really some Weberian prejudice. Or maybe prejudice is too strong. But states are still monopolizing the legitimate use of force. They are not exercising it, but are the ones who are doing the authorizing. So if you have the monopoly of the legitimate use of force, it doesn't mean you have to do the fighting. It means you get to say who legitimately uses force. I don't think there is any necessary or definitional reason why modern states couldn't do that and still be viewed as fully sovereign, if they were to choose to not have their own citizens to do the fighting. France still maintains the Foreign Legion. They have their first class military, but they also have the Foreign Legion. 
In terms of the language of legitimation, I am actually not too familiar with what the discourses have been surrounding the deployment of PMCs. My inference would be that it has to do with 'not expending American lives', even though many soldiers in PMCs are U.S. ex-military. I think it is generally presented as somehow less offensive to the sensibilities of the public if mercenaries are getting killed on our behalf, even if they are Americans, than if good soldiers from the Corps of Cadets are giving up their lives. Their lives are important and sacred, while the lives of mercenaries are expendable. Talking about the valence of terms, you use mercenaries once in the question and switch to private security companies, and of course those companies strenuously avoid the use of the word mercenaries.

Ultimately, my point is that is it not any sort of necessary challenge to our understanding of sovereignty for a modern state to employ mercenaries. It is built in the US understanding of itself. There is a long history of it. What we are (or were) doing in Iraq is not necessarily that novel, except maybe in scope, because that was really the Americans' first largely privatized war. It wasn't just corporate actors doing some of the fighting, but all of the other stuff as well. It was a war fought by Cheney's big Company Halliburton. That was not America versus Iraq, but Halliburton versus Iraq with the US providing some additional resources. But the food services and all the logistical training were privatized. I actually sometimes think that the phenomenon of that stuff being privatized is almost more interesting than the war fighting being privatized, because the war fighting part of it is not new, but the privatization of everything else is more novel.

Francine R de Paula: Do you think that the fact that most contemporary conflicts have been categorized as intra-state conflicts could more easily enable the 
delegation or the authorization of the use of force to private military companies, since there are no direct national interests in the fight, as in the cases of humanitarian interventions?

Harry Gould: If we switch gears to international law, the law there is very clear that if you send them [private military companies], they are an extension of you for legal purposes, whether they are mercenaries, or the Contras in 1980s. So maybe in terms of public relations back home, it is easier to do it when you are not sending your citizens to die. In terms of the other external aspects of sovereignty, and the issues of obligations related to the external aspects of sovereignty, for those purposes, it is really irrelevant whether they are regular uniformed military, mercenaries, or just nationals of that same country equipped and supplied and sent by you.

Kent Morris: I was thinking of Machiavelli.

Harry Gould: Yes. There is the idea in Machiavelli that mercenaries are not trustworthy. It was Rousseau who called them useless and flabby. "They will fight and die for you as long as there is no fight going on". Now we have this phenomenon that you get the guys who are all 'gung-ho' about killing without having any of the restraints that they would have as normal uniformed military.

Kent Morris: Dr. Steele, I would be interested in hearing how you came up with the idea of "aesthetic insecurity," the moments, points, or events when you began to develop a clear vision and application of the concept. How might this concept help explain the discursive construction of "national security," "insecurity," and "crisis," which are dominant discourses in US identity formation? 
Brent Steele: I don't know where the hunch developed, but I think for me the function of developing this perspective of aesthetic insecurity came as an initial response to the neo-conservatives in the early 2000s, and their influence on U.S. foreign policy. If not ubiquity, at least the high frequency with which I heard references, maybe not voiced in this language, to what the U.S. looked like when they were doing something and how they couldn't look like. And if that's the case, that's an interesting move that we had not, at least up to that time, properly recognized.

Kent Morris: That America can't look weak.

Brent Steele: Exactly. So it is not whether America is weak. We have no discussion of what the ontology of weak and strong is. We have a discussion on how they are represented. I was reading Foucault's late work on aesthetics, and a little bit of Dewey on aesthetics. And then I started looking at some of the intellectual writing by some of these neo conservatives - not necessarily the ones who were working in the Bush administration, but those who were writing in the 2000s and who had been writing since the 1960s, like Norman Podhoretz. If you look at some of his writings in the 1960 s, you see these very bizarre things. He wrote this famous essay on "Our Negro Problem." He has an overarching argument of being a Jewish kid growing up in Brooklyn or the Bronx and getting beaten up by African Americans. Now, he does claim that the way in which you overcome this "Negro Problem" overall is that America needs to not segregate the "negros" in certain areas and move out to white suburbanite areas, but that one needs to engage the "negro" perhaps in a more collaborative way. When you read through that essay, he has some of these bizarre references. He talks about watching the 
"negro" dance on the dance floor and aching with all of his body that he wished that he had the grace, the style, and the beauty of it. And you think: where is he coming from here? But there was sort of an aesthetic sentiment that he was developing, and you will see it also in the 2000s when he makes references to how the United States can't withdraw from Iraq in a column entitled America the Ugly. And all of this is coming out by the time I was writing Defacing Power. And the idea is not that the United States needs to withdraw or stay because of what is happening in Iraq, but because you don't want it to look like 1975 in Saigon.

Kent Morris: Or Carter in the Iranian hostage crisis.

Brent Steele: These are aesthetic memories of past history when we looked weak. So we can't look weak again and withdraw from Iraq.

Kent Morris: Carter was weak and Reagan was strong.

Brent Steele: Exactly. Even though Carter was the one who gave the 'go ahead' to that secret operation. It just didn't go well. But again, the way in which they construct this aesthetic security through language, discourses or rhetoric is using historical images as either a negative representation of what the United States was and how it has to combat that with what it needs to look like in the here and now. And the concern is that it will even translate into a physical security. They never ever detail how this would happen, and then it became an end in and of itself, that aesthetic security was security. There wasn't "you can't look weak, because that will lead to the barbarian hordes knocking down our walls." It is just that you can't look weak, because you can't look weak.

So there is this sense in the 2000s, especially when it came to the conduct of the Iraq war, when there are all these aesthetic representations that could be 
inherently challenged, because you idealize them. If you think about the cosmetic angle to it, it is making you look like something else than you think you are. You have an idealized representation of what you should look like and you're constantly trying to strive for that. But just like supermodels and airbrushing or whatever else, there is no way you can strive for that all the time. So you are inherently set up to be insecure, and that's the meaning of insecurity. It is a special type of insecurity that is a little bit different from our typical understandings of insecurity. But an insecurity that I think is, if not prevalent, as much of a factor. Maybe not a cause or an intent, but as much of a factor in the security practices, violent practices and reactions of the United States, especially in the 2000s, than a typical sort of national security drive for power interests as described by political realism. That's not happening in the 2000s, but nobody seems to be noticing that move, that this seems to be what war is about, or what violence is about. It is about what you look like, and not what you are. That was interesting to me and it provided an opportunity.

I see rhetoric and discourses of it in the construction of national security and insecurity. When you think about crisis in terms of aesthetics of security or insecurity, it is a crisis over representation and how you look. If that's the case, you look insecure, because there is no way that you're going to be able to overtake a hegemon physically, theoretically. This also leads toward the intersections with classical realism that we are coming from. Some of the classical realists were very agent-centered, arguing that the only thing that has really unsettled hegemons was hubris, and not tragedy. It was their own agency that got in the way. And that's what is happening here with a formulation of security as connected to aesthetics. 
You're easily manipulable. It is easy to tweak someone that has this idealized understanding of who or what they are. It is harder to tweak someone at an individual level who doesn't really give a damn about what he looks like. But you can inherently and quickly, momentarily at least, tweak or cajole or insecuritize an actor that focuses on crafting an aesthetic self. So, in that case, the United States looks on the one hand "powerful" and, in the 2000s, it also looks inherently powerless because it could so easily be manipulated.

We forgot the contractors from Blackwater that hung from the Fallujah bridge. We don't talk about them as even being contractors, because there is immediately the construction of the historical images... This is Blackwater Down! And they substitute the references of Black Hawk Down at the time of the situation at the Fallujah to the idea: Black Hawk down. This is what we looked like being dragged through the street of Mogadishu and we went through. We can't do that, so we have to react to that vision. And they are not even really reacting to the vision of Fallujah, they are reacting to a hallucination of what was going on in 1993 represented in the form in 2004 of what we need to do, because that's what we did before. And we need to do something different now. So we look different, we look more powerful.

To me, that's something that gives you empirical leverage, because the operation that they had after the initial Fallujah contractors situation in the Spring of 2004 went on, it blew up a bunch of stuff, and then it went through and they ended up handing over Fallujah to a former Iraqi General under Saddam Hussein. And you have all these military journals, saying that this didn't make any sense. No, it doesn't make any sense if you think of military objectives as being connected 
to some sort of operational goal. But if it is all about looking like something, it makes perfect sense. It is abhorrent, but it makes perfect sense.

Kent Morris: More so than just the objectives of the state, how strong or relevant do you think this is for securing a sort of fixed and set identity for Americans and their perception of domestic legitimacy and authority?

Brent Steele: I think it is inherently important. Some of my work is just springboarding from this. I would never put it in the same category of some persuasive, effective books, like David Campbell's work on America in Writing Security, about it being the ultimate imagined community. His interpretation of American security policies was basically that it is somewhat decentered and can't go about doing all of these things and trying to securitize what America identity is. He shows in his dataset all these weird national security memos that were supposed to be classified, but they are still using these discourses to try to securitize American identity. I am kind of springboarding from that and saying that this inherent groundlessness also can be manifested even more in an America subjecting itself to an aesthetics of insecurity. Some of the critiques I received from friends, like David McCourt, have been about "I am British and I get it. It sounds really American. You've got the US in 2000s paid. But sometimes we speak the language of social sciences and if we don't consider ourselves social scientists, how can we extrapolate or generalize about the others." I think there are aesthetic elements of it. But the aesthetics of insecurity, the ramping and hyper aesthetics of insecurity is really something that is prevalent in the US American experience, and some of it goes back to where Campbell is coming from in that book.

Harry Gould: McCourt just missed it by a few decades in the U.K. 
Brent Steele: You're right. He is doing work on the Falkland Islands war. For me, this is interesting because that's the first war I remember as a kid. When I teach Intro to International Relations, I always ask all the students, freshmen and sophomores, to write down the first international event they remember. Some of them put Pearl Harbor. I don't think they've heard the question right. I specify that it is in their lifetime. Some of them put really strange answers. Some of them put princess Diana dying, which I guess is an international event. But a lot of them put 9/11. I always ask what they think mine was, and they say: "Vietnam?" I get a little concerned about that, not necessarily because they think I am old, but because I don't really think they know when the US experience with Vietnam was. But for me, that was the Falkland Islands war. I remember having one of those globes and asking my dad: where is the Falklands? He used to show me: down here, by Argentina. And I wonder: Why is this country ruling all the way down here? That was my first experience of an understanding of security interest that was almost completely devoid of any material content and that had to be representational. So, MacCourt's work showed that the roles that Britain was embodying were connected to British identity after World War II. This was an explanation for the Falkland aesthetic, recasting the British role as being a defender of the status quo rather than a former colonial power, even though it was going all the way down to Argentina and occupying these Islands. I think that's interesting and instructive. I actually do think that there is an element of aesthetic insecurity. I don't want to say it's inherent in all countries and even in nonstate actors. But there is an element of it that is inherent in the crafting of security practices. 
Kent Morris: You have argued that the "scars of violence" constitute their own powerful form of accountability. However, this is mediated because some meanings are inscribed while others are silenced. Which raises attention to the legitimacy of the author who is inscribing accountability. How, then, can the scar expose the responsibility of the perpetrator, rather than displace responsibility? Could environmental degradation, or poverty, for example, be seen as scars, which might expose that these wounds are created by those who appear to heal them?

Brent Steele: I actually think that the second question somewhat anticipates or helps me to answer the first question. The first thing I should mention in answering the second question is that I am aware of the conceptual limitations of the scars I am looking at, because they are not covering some of these forms of human deprivation that can sometimes be much more prevalent, empirically general and happening out there, and much more violent in terms of their effects on human beings, like environmental degradation and displacement.

These understandings of human security, if we want to call it that, are really not covered by the types of scars that I am focusing on. But that being said, the point that I was trying to make with the scar was that, because it is open, because it is a mark, it is temporary and permanent, the opportunities for going in and providing an account are seemingly endless. It resists one dominant reading, rendering and covering over it, excluding others. That doesn't mean it doesn't happen. One of the cases I look at is the Emmett Till case. We are still not $100 \%$ for sure what happened in the Emmett Till case, even though the FBI had this huge investigation in 2004 and it was also investigated in the 1950s. And that's in the domestic 
hierarchical settings of the US where we should be able to come up with some form of accountability and an account of what happened.

But this is a problem, because we are not then able, getting back to the basis of this question, to locate the perpetrator responsible for it. But it is also an opportunity, because it means it focuses on some type of reflection, and not just a matter of who is responsible for this. There is a response to the scar. That's my understanding of responsibility with autonomy that I am teasing out. If we respond to it, we don't identify just one person. We might have a possibility of reflecting on other processes besides just the initial perpetrator that did it, that could be responsible for, if not causing that particular scar.

I am writing this in the wake of the 2000 s and, to me, it feels that there is no form of accountability going on, for the people who tortured, the people who gave the orders to torture, the people who initiated the Iraq war that became a catastrophe. It doesn't feel they are being held accountable, with the exception maybe of what we call vertical accountability in terms of the voting booth. But for me, when this sort of aspect of accountability really came through - and again I am using bodies of others to do this, which is problematic in and of itself - it was roughly in 2006 or 2007 at the University of Kansas, which is fairly close to Fort Leavenworth, which has a huge military presence, obviously. So, we are used to seeing students who are in the military and also students walking around sometimes in their uniforms. There was one day when I was in the library and I saw a student walking by and everybody was looking at him. And it was someone who was far younger than I was, roughly the age of the students I was teaching at the time, and he was injured with a scar in his face and his leg was partially 
amputated. What is interesting to me is the reaction that this stimulated amongst the students who were walking across campus. Because then the scar is right there, and yes, maybe you can provide the clichés, the reasons for why that person had to go over to Iraq. But when the scar is open and it is contestable, you might have to resist that sort of simple explanation. We can do that when it is not in front of us, but it is more difficult when it is in front of us. That felt to me like a possible way for an alternative type of accountability, that we don't recognize, that actually could be, I think, in some ways, more poignant and powerful at a ground level than even formal mechanisms of accountability could be. Even though we feel more satisfied, satiated, or gratified by the formal accountability mechanisms: somebody being tried by a jury and then executed, or whatever. But, sometimes, there are these other forms that I think are important.

But it is a problem, too, because the most effective part of this alternative form of accountability, for me, is when the perpetrators haven't been held to account. Even in formal accountability practices, like truth commissions, you see a lot of references to scars, where people have to face down the people whom they impacted. So there is an element of speaking or narration that is there that provides a particular account that challenges what might have produced the violence in the first place. Including the perpetrator, who is primarily perhaps responsible for it, but also the community within which these things happened, and who are responding to it. So when I see all those students on campus reacting to this, the idea is not just "oh, this is one or two people that sent that person over there." But there were a lot of people driving around with flags saying "Let's Roll" in the back of their cars in 2003. And it wasn't just Bush and Cheney. So it is 
socializing responsibility a little bit, which is problematic, because it doesn't locate a person or individual. And I know where he [Harry Gould] comes from in terms of what should be held accountable and what should be criminalized and what can't be criminalized, but at least in terms of forcing a response and what is facilitated and made possible, Iraq and the re-inscriptions of why it was necessary, the community also has to be involved in that as well and reflect on its role in doing that. For me, that's also the purchase of that kind of accountability, even if there is a problem with it in terms of socializing responsibility.

Kent Morris: The notion of scars I think it is interesting in terms of environmental degradation as well. I kept thinking fracking, mountain top removal. You see these aerial photos, especially from lower western Virginia, southwest Virginia, and that there are really scars on the face of the planet and the ramifications of fracking on water. I think that what you're doing with the scars could be a good avenue for discussing this in a larger understanding of accountability, implicating communities and perpetrators, specifically companies that engage in these practices.

Brent Steele: When you read a little bit of what was supposed to be the progenitor, or at least the literature basis, of some of the green political theory like Aldo Leopold's A Sand County Almanac...

Jennifer Lawrence: .... which is a romanticized version...

Brent Steele: Exactly. But I mean, that fact that you have the sense of what the landscape looked like. And I do engage landscape scars, the ones that are there [in the book] are related to bombs. I don't deal with this, but I think you can deal with this very persuasively. 
Jennifer Lawrence: Borders have also been used as an example of a landscape.

Brent Steele: Yes. Oded Löwenheim wrote a book called the The Politics of the Trail. It is his new book with Michigan Press. It was about riding his bike in the hills of Jerusalem. Everyday he had to ride the bike to Hebrew University and he'd seen the fence every single day, being built and being constructed between the Palestinians and the Israelis. I think there is an effect and it is a different content of effect when it comes to architecture and landscape than it is perhaps with bodies. There you actually can do interpositioning. You can actually get inside the empty space that is both a presence and an absence. But then there is also the scar on the sort of landscape or panoramic view that you notice immediately. So you can see one angle of this coming down and that's an obvious scar. But then [there are] also [hidden scars]. Whenever you go past Mount St. Helens, you know that it is there, that it is a volcano, and that it erupted even if it was thirty years ago. You can tell, when compared to Mount Rainier, that in Mount St. Helens something has happened.

And that's our perception of mountain top removals, it is obvious. It is obvious that something was removed and something was done to that. On the one hand, it is very powerful, in terms of the effects that we see visually. On the other hand, does it generate enough of a response to contest and problematize all of the things that might be responsible for that mountain top removal and all of the people that are embodying the practices that lead to that as well? I am not sure. I would hope so. I would hope it would the same way that some of the scars on the bodies of people I look at in the Scars of Violence generated some resistance or mobilization. 
But I don't know enough about environmental issues, or environmental politics and processes, to be able to test that.

Kent Morris: But maybe more so than companies as perpetrators, it would implicate all of us, because of our desire for energy and the demand of the system which allows for this...

Brent Steele: Patrick Hayden has written a book on political evil where he draws from Arendt. Arendt is always trying to be cautious and say "we can't all say that we're responsible, because then nobody is responsible." But then Hayden also represents environmental degradation and global neoliberal economics as forms of evil, or of the banality of evil. While, rhetorically, this is a little bit sensational or provocative, I think there is also some purchase in that in terms of the ways in which we can at least both socialize and individualize responsibility by recognizing questions we should ask: why are we consuming so much? Why do we need this energy? It is not just the how is it possible, but about the why questions that this can generate which I think is useful. But again, that's under the understanding that formal mechanisms of accountability for this are never going to happen. So you're pretty much surrendering that for an alternative form of accountability that might leave a lot of people fairly unsatisfied.

Kent Morris: What tactics or strategies do you use in your scholarship to avoid discursive traps whereby the ideas that you are trying to unsettle become reinforced through your writing?

Brent Steele: If you look at a couple of articles I published in 2005 and 2006, one in the Review of International Studies on ontological security and Britain not intervening in American Civil War after the Emancipation Proclamation was issued, 
and the other I wrote with Jack L. Amoureux on the human rights panopticon in the form of human rights NGOs. If I say that to you, ASPECT students, you would say that this sounds really provocative and exciting. But if you look at the way that we constructed the arguments, they're almost like a different version of rational choice theory using that language. I was trying to say that there is a different form of rationality that is out there that is connected to identity. And if you put it in those terms, you are reinforcing through these discursive traps that which you want to unsettle. I was saying that everything is rationality, and we need to understand a different kind of rationality. I try to argue that being humanitarian is rational because it is connected to identity, and so instead of just physical security, you have ontological security and rational policies that uphold ontological security. That's inherently problematic. And I was also writing by the time I was a graduate student and some of that was strategic because I was thinking that I needed to use a certain language if I wanted to get published in a particular journal.

So in terms of strategies or tactics that I use in my scholarship now, I look at my old scholarship and see the extent to which I did that and I try to chasten my language. And another thing that I am doing is to use quotation marks. I am using quotation marks to say "this isn't mine, this is somebody else's understanding of power. And by the way, I don't think that's a very good understanding of power, because it can almost be inverted and become powerless or less powerful." That's one of the other things I do, but if you're doing that, you can play that game all day long and every word in the entire book is in quotations. Language and writing are inherently intersubjective, and there are power relations in writing as well. Inherently, you are already giving in to some of these traps that have been set 
before you, if you want to define an audience or to get things published. It is really like a competition between courage and caution, and it goes down to the level of how we write.

Harry Gould: Bearing in mind what I said last night, I have not generally thought of myself a as critical scholar per se until I got the invitation to this event. I haven't generally been as reflective as I might be or should be about how I write. If I think about the ways in which I often write, pulling apart accumulated layers of meanings, and reminding readers that there are these layers and each of them brings certain burdens and certain histories. I guess the only potential trap I see is just that that work is not complete, even though I am taking the step to say: hey, there is this stuff you've missed, and it still has influence down to today. But the door is still open that I've missed some of it and somebody can come along and say: yes, and you've missed all of this. But I don't know if that is a discursive trap per se or that I am reinforcing what I am trying to criticize, other than that recognition that when I am pointing out that people before me were careless, if I am then missing things, I am myself then careless and showing that just calling people out for lexical errors or carelessness has its own risks. I think the structure of Brent's work is much more attentive to these issues just in terms of thinking about how he writes.

Francine R de Paula: In a way, wouldn't your way of de-essentializing meanings by separating denotations and connotations be a good way to not fix any meaning to some terms and avoid these traps?

Harry Gould: Sometimes I may still find myself trying to work out, not a fixed meaning and not even an operational meaning, but I do reach some points. For 
instance, in the book on prudence that I am writing, I am trying to put forward an understanding of prudence. And it might be read as me offering "here is the definition," which I am going to great pains not to do. But I suppose that ultimately by saying "here is how I think we might most fruitfully conceptualize these," even though I have those caveats, the door is still open for me to try to essentialize it.

Kent Morris: Are there aspects of traditional international relations that are still relevant for post-positivist IR scholars? What concepts remain foundational to the field of IR so that post-positivist readings of international relations remain distinctly recognizable as IR scholarship?

Harry Gould: Intention.

Kent Morris: For instance, what should we take from Waltz or Morgenthau?

Brent Steele: What is traditional international relations? That's an open question and it provides opportunities.

Harry Gould: We are not going to want to throw out concepts. We are going to throw out conceptions and conceptualizations. Nobody is going to say: "let's not talk about power anymore." The problem isn't with the concept.

Jennifer Lawrence: What do you have to do to be part of an IR "club" as opposed to IPE or something else?

Brent Steele: The discipline provides some material to begin to construct your own arguments by referring to other presentations and representations of that traditional IR scholarship in the past. I have been part of the movement of the last 10 years of reengagement with classical realism, of resurrection of Morgenthau, Niebuhr and Herz. All of these realists who were writing in this very delicate time, in the 1940 s and 1950 s, started to be represented as being "scientific" enough' by 
neorealists, as the only thing we need to know about traditional IR scholarship before the 1979. You had people who were not satisfied with that in the late 1990s and especially in the 2000s, that were embodying realists as a frame of reference to springboard into more postpositivist or poststructuralist types of arguments. Michael Williams says in some of his conference interventions that the reason he uses Morgenthau, Carr and Hobbes instead of Foucault is that people listen to you if you use classic realists. What is great is that that unsettles our understanding of what traditional IR scholarship was. A little bit of this people don't like because it is not considered scientific, but it is more like intellectual history when you go back and try to establish the context in which they wrote.

You have critical scholars, even Robert Cox did this with Carr, re-embodying some of that work or those voices of classical realism for their own purposes in particular contexts. That to me is one function of traditional IR. And the concepts themselves, at least they provide a frame of reference from which to do the same thing, say 'this is how anarchy is conceptualized... it is not a core concept, but it is conceptualized in different readings' and then you go from there. The one thing I would get rid of is the neo-neo debate. This is a debate that can be represented to freshmen in college in a $2 \times 2$ matrix.

Harry Gould: Absolute versus relative gains.

Brent Steele: Yes. Done. They spent so much time in the 1980s dealing with that. Those neo-neo debates should be in the dustbin of history.

Harry Gould: We can't de-familiarize concepts without using them. While they are still current, they still give us something to play with. There is still a lot to be said about traditional concerns, about how we understand the state or sovereignty 
or power, or more recently, the questions of agency and structure, about the system. There are still reasons to keep them in the vocabulary. They are still part of a common vocabulary. There are still things left to be said about them. There are problems with revisiting all these authors, too. I was in a panel on 2010 and there were three people presenting different perspectives on Morgenthau; three papers proposing: Morgenthau + a specific reading $=$ real Morgenthau. After a point, one gets a little tired of it. When Vendulka Kubalkova reread Carr as a constructivist, that was pretty novel, versus the notion that "we really need to read more of Morgenthau according to French writings of international law to understand what he really meant."

Brent Steele: As long as you set up why you're doing a rereading, you get the idea that there is never going to be an original or right way to interpret it. Do you have the ability to persuade people that this is another account or reading that comes out of Morgenthau or Carr? For me, Laura Sjoberg's recent move toward a structural theory and systemic theory from a gender hierarchical perspective has and produces the punch because of the comparison to Waltz, and in this sense, Waltz is still useful. What she is doing is provocative, because then if you read Waltz's understanding of structure as being a distribution of power, it turns out to be an oversimplification of what the world is. Here, Waltz is a reference point that then provides a very creative basis to springboard into another way to represent, understand, and theorize the world. And I think the classics do provide that function as well. The one thing I always resist though is when people say that what you say has already been said. That's a form of power. It excludes what you are saying for being similar to what is there. I think it also can be lazy. I really see this 
with other generations of IR scholars that have been saying to the way that I read Morgenthau or my take on the world, that we were all having these debates in the 1950s, 1960s, and 1970s. And then when I ask what those debates are, there is no resemblance to the arguments I just made. So I think there are those simplifications being made, but also regimes of authority that are problematic. But keep in mind what Harry just said. If you're making Morgenthau into everything, you're making him into anything.

Harry Gould: I want to dissent just a little bit. I agree with the overall comment, but sometimes people really are reinventing the wheel. It is not necessarily lazy to tell them that, because sometimes the fact is that they have not done their homework, they have not read the history of the debates. They are not aware that the conversation has been explored in a lot of other ways they are not looking at.

Brent Steele: It is only going to get harder to teach graduate students how to be graduate students, because there is so much more scholarship out there, so many readings and alternative readings that cannot be covered in graduate school. We were learning 10 or 15 years ago in our graduate program that there was a lot that had been done in the previous 15 years. Now you need to graft on all of that in addition to everything else.

But then to the extent that you are saying something is different from what was said before, you are presented with the counterargument that you are saying what somebody else has already said. If this is not the case, then at least you are forced to provide a finer point about how your work, if not unique, is a little bit different or modified compared to the arguments presented before you. 
Harry Gould: If you say that to somebody [that their arguments are not new], in your role as some sort of disciplinary authority, you have an obligation to not just say "it has been done before, don't bother," but to tell them who did it and what they did with it. You can't use that as dismissal. By invoking that power, you are placing yourself under an obligation to tell that person.

Brent Steele: Which is why a good discussant or chair at a conference, or a reviewer or editor of a journal would do that. Those are the spaces where this tends to happen. 